\title{
EKSEKUSI HAK TANGGUNGAN YANG DIPAILITKAN
}

\author{
Luh Putu Ari Tiarna Dewi ${ }^{1}$
}

${ }^{1}$ Luh Putu Ari Tiarna Dewi, E-mail: ari_tiarna24@ymail.com

\begin{abstract}
Info Artikel
Masuk : 23 September 2019

Diterima :28 September 2019

Terbit : 30 April 2020

Keywords :

Execution, Encumbrance

Right, Bankcrupty.

Kata kunci: Eksekusi, Hak

Tanggugan, Pailit

Corresponding Author:

Luh Putu Ari Tiarna Dewi, Email:

ari_tiarna24@ymail.com

DOI :

10.24843/AC.2020.v05.i01.p09
\end{abstract}

\begin{abstract}
The legal relationship arising between the debtor and creditor raises to fulfillment achievements. To guarantee the legal certainty of these achievements with encumbrance right. To fulfillment of achievement does not cover the possibility of the existence of constraints experienced by the debtor. On the debt in the fulfillment of the achievement, a debtor could be declared bankrupt if he has two or more creditors that have a debt that is insolvent. As a debtor in bankruptcy, then management will treasure the debtor becomes lost and gives rise to legal consequences for the deeds of the law which he did without exception have an impact on his charge. This led to a dispute the right of execution of the holder's rights to the dependents. The existence of restrictions in suspension of right to execution as determined in article 14 encumbrance right and article 55 paragraph (1) law of bankcrupty with article 56 paragraph (1) law of bankcrupty. Focus of the research problems are how the execution rights of dependants in accordance law of encumbrance right with law of bankcrupty? And whether it is fair for creditor rights holders and other creditors dependents in bankruptcy? As for the purpose of this research is to find out how the execution rights of dependants in accordance law of Encumbrance Right and Law of Bankcrupty and know justice for creditors rights holder dependants with other creditors by looking at the framework of the concept of the existence of the suspension of rights. This type of research is the normative research. The conclusion is the executable is accordance with encumbrance right due to its lex specialists.
\end{abstract}

Keywords: execution, encumbrance right, bankcrupty.

Abstrak
Hubungan hukum yang ditimbulkan antara debitor dan kreditor
menimbulkan suatu akibat hukum yakni pemenuhan prestasi.
Untuk menjaga kepastian hukum dari pemenuhan prestasi
tersebut sampai-sampai dimestikanlah suatu jaminan, salah
satunya dengan jaminan kebendaan Hak Tanggungan. Dalam
pemenuhan prestasi tidak menutup kemungkinan adanya
kendala-kendala yang dialami oleh debitor. Atas utang dalam
pemenuhan prestasi, seorang debitor ditetapkan sebagai seorang
yang pailit jika ia ada dua atau lebih dari dua kreditor yang
mengantongi utang yang habis masa dan dapat ditagih. Dengan




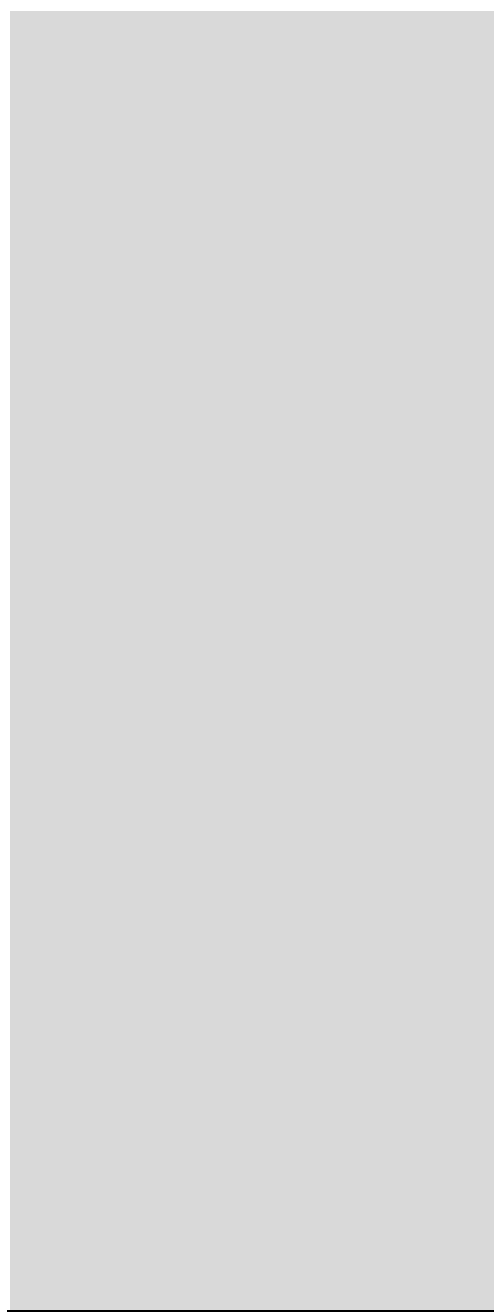

status hukum selaku debitor pailit, maka kepengurusan akan harta kekayaan debitor menjadi hilang dan menimbulkan akibat hukum bagi segala perbuatan hukum yang dilakukannya tanpa terkecuali berdampak terhadap Hak Tanggungannya. Hal ini menimbulkan pertentangan hak eksekusi dari pemegang Hak Tanggungan. Adanya pembatasan dalam pengeksekusian sebagaimana ditentukan dalam Pasal 14 Undang-Undang Hak Tanggungan dan Pasal 55 ayat (1) Undang-Undang Kepailitan dengan Pasal 56 ayat (1) Undang-Undang Kepailitan dengan adanya penangguhan hak atas pengeksekusian. Sehingga yang menjadi fokus permasalahan penelitian adalah permasalahan yang dijadikan fokus penelitian adalah bagaimana eksekusi hak tanggungan sesuai Undang-Undang Hak Tanggungan dan Undang-Undang Kepailitan? Dan apakah hal tersebut adil bagi si pemegang hak tanggungan dan kreditor lainnya dalam perkara kepailitan? Adapun tujuan pendalaman studi ini adalah untuk menyelami bagaimana eksekusi hak tanggungan sesuai Undang-Undang Hak Tanggungan dan Undang-Undang Kepailitan dan mengetahui keadilan bagi penagih utang selaku pemegang hak tanggungan dengan kreditor lainnya dengan melihat kerangka konsep adanya penangguhan hak. Jenis penelitian ini ialah penelitian normatif. Kesimpulan adalah eksekusi dijalankan sesuai dengan Undang-Undang Hak Tanggungan dikarenakan sifatnya lex specialis.

Kata Kunci: Eksekusi, Hak Tanggungan, Pailit.

\section{Pendahuluan}

Seorang debitor dan kreditor melakukan suatu hubungan hukum. Dikatakan melaksanakan suatu hubungan hukum dikarenakan menimbulkan suatu yang harus dipenuhi yakni hak dan hal yang harus dilaksanakan serta dijalankan ialah kewajiban yang dilekatkan pada tiap-tiap pihak. Hubungan hukum terjadi antara 2 atau lebih dari 2 orang nan memautkan dirinya pada suatu perikatan hukum. Pihak yang berhak atas prestasi atau dapat dikatakan sebagai kreditor yang bersifat aktif memiliki piutang, sedangkan pihak debitor atau pihak sifatnya pasif dan mempunyai utang sehingga ialah harus membayar prestasi. Debitor sama dengan orang yang berutang dan menyanggupi pelunasannya yangmana dalam pelunasannya dapat dituntut di depan meja hijau . ${ }^{1}$ Sementara itu Kreditor adalah orang yang berpiutang karena yang dapat menuntut debitor di meja hijau. ${ }^{2}$

Asosiasi hukum yang terjadi diantara debitor dengan kreditor, pastilah terjalin lantaran adanya sasaran yang diperjanjikan. Atas pemenuhun kewajiban tersebut dinyatakan pemenuhan suatu prestasi sebagaimana ditentukan dalam Pasal 1234 KUHPerdata. Sebagai objek hukum atas suatu yang diperjanjikan maka perlulah

1 Sutan Remy Sjahdeini, 2010, Hukum Kepailitan: Memahami Undang-Undang Nomor 37 Tahun 2004 tentang Kepailitani, PT. Pustaka Utama Grafiti, Jakarta, h.93.

${ }^{2}$ Ibid. 
diimbangi dengan beban tanggungan untuk melindungi kepastian hukum atas prestasi yang harus dipenuhi. Bilamana suatu beban tugas antara kreditor dengan debitor ini tidak ada, maka kewajiban timbal balik atas prestasi yang harus dipenuhi dianggap tidak ada artinya menurut hukum.

Kewajiban atas menyerahkan prestasi dalam istilah asing disebut schuld, dan kewajiban debitor memberikan kekayaannya untuk direnggut oleh kreditor sejumlah seluruh kewajiban atas tunggakan debitor guna pengimpasan utang dan apabila si debitor tidak melaksanakan pemenuhan dalam pembayaran utangnya disebut dalam istilah asing ialah haftung. Oleh karenanya, perlu adanya jaminan atas prestasi yang diperjanjikan. Pasal 1131 KUHPerdata menjadi dasar dalam melihat pentingnya kedudukan objek yang diperjanjikan. Sudah semestiya terdapat jaminan untuk mengkover dan menjaga kepastian hukum untuk pihak-pihak yang bersangkut paut atas pelunasan utang-piutang yang salah satunya dibebani jaminan Hak Tanggungan.

Hak tanggungan dimaksudkan hak pembebanan jaminan yang diberikan pembebanan terhadap tanah disertai seluruh hal yang berkaitan dengan objek tanah mengikutkan atau tidak atas benda-benda lainnya yang masih tercangkup menjadi satu dengan objek tanah yang diperjanjikan itu untuk pemberesan dalam pembayaran suatu utang. Jaminan hak tanggungan dilihat dari unsur-unsurnya yangmana diatur dalam UU 4/1996 Pasal 1 angka (1) atau selanjutnya disebut UUHT, adapun unsur pokok yang terkandung yakni: "hak tanggungan dimaksudkan sebagai hak pemberian pembebanan jaminan yang akan dijadikan sebagai pengkoveran utangnya dan menjadikan ia kreditor yang diutamakan." 3 Sehingga diketahui bahwa jika debitor yang tidak beriktikad baik dalam memenuhi janjinya atau dikatakan "cidera janji" atau lazim dikatakan sebagai "wanprestasi", sampai-sampai si kreditor Hak Tanggungan memiliki hak untuk menjajakan objek yang diagunkan melalui lembaga pelelangan umum atas objek tanah yang disiapkan menjadi suatu objek agunan tunduk pada keputusan peraturan perundang-undangan yang legal dengan mendahulukannya ketimbang kreditor pemegang agunan lainya atau kreditor lain yang mempunyai hak sehubungan dengan pemulangan piutangnya.

Adapun sifat-sifat dari Hak tanggungan ialah:

a.Droit preference artinya menjadikan ia pada posisi yang didahulukan atau diutamakan kepada pemegangnya.

b. Droit de suite artinya selalu menyertai obyek agunan pada tangan siapapun obyek itu dikuasai.

c.Menjalankan asas publisitas dan spesialitas, yang membawa dampak mengikat dan berpengaruh terhadap keberadaan pihak ketiga serta memperoleh kepastian hukum bagi siapapun yang memiliki keperluan atas objek tersebut.

d. Mudah dan pasti pelaksanaan dan pembagian atas hasil eksekusinya."4

Atas dasar Pasal 14 UUHT5, sertipikat Hak Tanggungan digunakan menjadi tanda diri penguasaan atas diperolehnya Hak Tanggungan, yang dimana pada kepala sertipikat hak tanggungan menyisipkan dan menyematkan irah-irah "DEMI KEADILAN BERDASARKAN KETUHANAN YANG MAHA ESA" dimaknai bahwa

3 Paputungan, Nina. "Kajian Hukum Hak Tanggungan Terhadap Hak Atas Tanah Sebagai Syarat Memperoleh Kredit." Lex Privatum 4.2 (2016), h.23.

${ }^{4}$ Boedi Harsono, 2007, Hukum Agraria Indonesia: Sejarah Pembentukan Undang-Undang Pokok Agraria, Isi dan Pelaksanaannya, Jilid I, Djambatan, Jakarta, h.420.

${ }^{5}$ Lihat Pasal 14 ayat $(1,2,3)$ UUHT. 
SHT menyandang otoritas eksekusi yang sama berpegaruhnya serupa putusan meja hijau yang mana memiliki otoritas hukum mengikat dan tetap (inkracht van gewijsde). Nilainya ialah putusan hakim itu harus tunak/tunduk bagi pihak yang berkepentingan dan mengikat serta tidak ada lagi kesempatan mengupayakan kembali adanya upaya hukum lanjutan (recthsmiddel). ${ }^{6}$ Dengan dicantumkannya irahirah tersebut diatas pada SHT untuk menegaskan bahwa hanya dengan sertipikat tersebut bersifat mengikat dan berkekuatan hukum tetap yang menyokong hak untuk pemegang SHT untuk mengeksekusi secara langsung sehubungan obyek yang menjadi jaminan dan eksekusi tetap berlangsung tanpa adanya putusan pengadilan yang memerintahkan untuk mengeksekusi obyek yang dijaminkan tersebut karena obyek tersebut siap untuk dieksekusi. Adapun pengeksekusiannya tersebut melalui prosedur dengan memanfaatkan kewenangan dari lembaga parate executie sehingga mempermudah jalan untuk memperoleh pelunasan atas utang yang tidak dibayarkan oleh debitor. Selain hal tersebut, untuk hajat kreditor laksana pemegang HT disediakan tambahan perlindungan yang diatur pada Pasal 21 UUHT, mengatur terkait Pemegang HT memiliki hak sepenuhnya atas jaminan yang diperolehnya melekat segala hak atas agunan tersebut. Hal tersebut memiliki keterkaitan dengan isi Pasal 55 ayat (1) UU 37/2004 tentang Kepailitan dan PKPU (selanjutnya disebut UUKPKPU) menentukan: "dengan tetap memperhatikan ketentuan sebagaimana dimaksud dalam Pasal 56, Pasal 57, dan pasal 58 setiap Kreditor pemegang gadai, jaminan fidusia, hak tanggungan, hipotek, atau hak agunan atau kebendaan lainnya, dapat mengeksekusi haknya seolah-olah tidak terjadi kepailitan". Maktub yang terkandung dalam pasal tersebut diketahui yakni pemegang HT memiliki penguasaan penuh atas benda yang dijaminkan dan lebih memantapkan kedudukannya sebagai pemegang jaminan berhak melaksanakan kegiatan lelang atas objek yang dijaminkan dan seakanakan tidak terjadi permohonan pailit. Kreditor pemegang SHT dapat memperoleh pelunasannya terlebih dahulu dan sisa atas pelunasannya tersebut barulah dimasukkan ke dalam boedel pailit pemberi Hak Tanggungan (debitor). Jika ditelaah kembali Pasal 55 ayat (1) UUK-PKPU, walaupun dianggap pengeksekusian atas jaminan kebendaan seperti halnya Hak Tanggungan tetap berjalan bagai tidak ada permohonan pailit, namun harus tetap mengindahkan pasal-pasal yang berkaitan.

Kewenangan dalam pengeksekusi yang diperoleh oleh lembaga Hak Tanggungan menjadi terbatas ketika seorang debitor dinyatakan pailit. Definisi kata Pailit merupakan kondisi si debitor insolvensi atau ia memang berniat tidak mau memenuhi tugasnya atas pembayaran utang-utang yang habis masa dan dapat ditagih oleh dua kreditor atau diatasnya. ${ }^{7}$ Atas kedudukannya sebagai debitor yang dipailitkan, hal tersebut menghilangkan haknya dalam pengurusan, menguasai maupun memindahtangankan harta kekayaan miliknya baik yang sebelumnya sudah ada maupun mendatang aka nada, akan masuk ke dalam boedel pailit termasuk juga objek yang dibebankan jaminan kebendaan. Berikut yang menyebabkan terjadinya berbenturan hak dan kepentingan dari pemegang Hak Tanggungan dengan kurator, yang bertugas untuk menampukan harta kekayaan debitor yang pailit.

\footnotetext{
${ }^{6}$ Luqmanul, M Hakim Bastary. (2010). Eksekusi Putusan Perkara Perdata. http://www.ptabandung.go.id/uploads/arsip/149Eksekusi_Perkara_Perdata.pdf . Diakses pada 21-01-2019 pukul 10.39 Wita.

7 Zaeny Asyhadie, 2005, Hukum Bisnis Proses dan Pelaksanaannya di Indonesia, PT. Raja Grafindo Persada, Jakarta, h. 225.
} 
Ditentukan pada Pasal 56 ayat (1) UUK-PKPU, memuat aturan mengenai penuntutan pemenuhan hak-hak atas para kreditor ditangguhkan sepanjang paling lama 90 (sembilanpuluh) hari sejak tanggal putusan pailit dilayangkan oleh majelis hakim baik atas hak pemegang HT maupun pihak ketiga yang berkepentingan untuk menuntut pengembalian hartanya. Dari isi pasal itu diketahui adanya jangka waktu penangguhan dalam mengeksekusi obyek yang dibebani hak tanggungan.

Pendapat dari Siti Heiranisya Cita Agca:

"karena adanya ketidakharmonisan antara pasal 21 UUHT dengan Pasal 56 dan Pasal 59 UUK-PKPU kewenangan yang diperoleh sebagai kreditor separatis menjadi tidak berfungsi sebagaimana kewenangannya karena berbenturan norma hukum antara pasal tersebut dan melemahkan kedudukan yang diperoleh sebagai kreditor separatis yang bakal mengeksekusi sendiri objek hak tanggungan tapi kedudukannya tetap menjadi kreditor yang diutamakan. Ketika debitor dipailitkan, kreditor separatis tidak diberikan kepastian hukum atas pelunasan utangnya akan terpenuhi sepenuhnya atau tidak. Hal tersebut menjadikan proses eksekusi menjadi lama dan tidak terpenuhi asas lex certa." 8

Atas hal yang disampaikan membuktikan bahwa benar adanya konflik norma atas pasal 14 UUHT dan pasal 55 ayat (1) UUK-PKPU dengan pasal 56 ayat (1) UUKPKPU. Hak eksekutorial obyek yang ditangguhkan pada debitor pailit menjadi terbatas. Yang seharusnya dengan adanya irah-irah sebagaimana ditentukan dalam Pasal 14 UUHT mempunyai hak eksekusi sebagaimana putusan pengadilan berlaku dan hak eksekusi yang seharusnya tetap dijalankan dengan seakan-akan tidak ada permohonan kepailitan seperti apa yang diatur pada Pasal 55 ayat (1) UUK-PKPU namun dengan adanya jangka waktu penangguhan yang ditentukan dalam pasal 56 ayat (1) UUKPKPU menjadi pengeksekusian atas objek tersebut tidak dapat dilakukan secara langsung dan terbatas dikarenakan pengeksekusian atas objek yang dibebani hak tanggungan harus menunggu 90 (sembilanpuluh) hari sejak tanggal putusan pernyataan pailit. Pentingnya adanya jaminan adanya keadilan hukum, kepastian hukum, dan kemanfaatan hukum bagi para kreditor dalam hal ini sebagai pencari keadilan maka diperlulah pengujian atas penerapan hukumnya.

Sesuai apa yang dipaparkan pada latar belakang tersebut kemudian dapat diasumsikan terdapat beberapa persoalan yang akan dijadikan fokus penelitian yakni bagaimana eksekusi hak tanggungan sesuai UUHT dan UUK-PKPU? Dan apakah hal tersebut adil bagi kreditor selaku pemegang hak tanggungan dan kreditor lainnya dalam kepailitan?

Orisinalitas dari penelitian ini setelah ditelusuri dari google scholar diperoleh beberapa uraian dari penelitian-penelitian sebelumnya sebagai berikut: pertama penelitian oleh Siti Heiraniscya Cita Agca berjudul "Harmonisasi Pasal 21 UndangUndang Hak Tanggungan dengan Pasal 56 dan Pasal 59 Undang-Undang Kepailitan dan Penundaan Kewajiban Pembayaran Utang Terkait Kreditor Separatis Pemegang Hak Tanggungan yang Melekat pada Benda Jaminan" ${ }^{\prime}$, kedua penelitian oleh Gede Adi Nugraha dengan judul "Hak Eksekusi Kreditor Separatis Terhadap Objek Hak Tanggungan Dalam Hal Debitor Pailit (Study Kasus Putusan No.

\footnotetext{
${ }^{8}$ Agca, Siti Heiranisya Cita. "Harmonisasi Pasal 21 Undang-undang Hak Tanggungan dengan Pasal 56 dan Pasal 59 Undang-undang Kepailitan dan Penundaan Kewajiban Pembayaran Utang Terkait Kreditor Separatis Pemegang Hak Tanggungan yang Melekat pada Benda Jaminan." Kumpulan Jurnal Mahasiswa Fakultas Hukum 1.8 (2013), h. 1.

${ }^{9}$ Ibid.
} 
06/PLW/PAILIT/2015/ PN. NIAGA. SBY JO. NO.20/PAILIT/2011/PN. NIAGA. SBY)"10. Dari kedua penelitian terdahulu tersebut diatas, belum ada yang membahas tentang keadilan hukum bagi pemegang jaminan Hak Tanggungan atas akibat hukum kepailitan sehingga penelitian ini merupakan kajian yang mempunyai nilai kontribusi baru dalam ilmu pengetahuan dan berguna bagi pemegang Hak Tanggungan maupun pemegang hak jaminan kebendaan lainnya.

Tujuan penulisan penelitian secara umum adalah untuk mengetahui perbandingan cara eksekusi hak tanggungan antara pasal 14 UUHT dan pasal 55 ayat (1) UUK-PKPU dengan pasal 56 ayat (1) UUK-PKPU yang tampaknya mengandung ketidakadilan bagi pemegang jaminan Hak Tanggungan dan sekaligus juga menjelaskan kerangka berpikir atau maksud kenapa adanya ketentuan khusus dalam kepailitan mengenai eksekusi Hak Tanggungan.

\section{Metode Penelitian}

Pengkajian suatu karya ilmiah sama dengan melaksanaan suatu kegiatan ilmiah atau penelitian hukum yang bersangkut paut dengan tata cara menganalisis dan mengkonstruksi atas suatu yang diteliti yang diljalankan secara sistematis, metodologis, dan koheren atas hal yang diteliti. Metode penelitian hukum dibedakan menjadi 2 macam, yakni: (1) metode penelitian hukum normatif yang meriset kajian hukum dilihat dari sudut pandang internal dan yang menjadi objek kajiannya ialah norma hukum dan (2) metode penelitian hukum empiris ialah cara atau jalan dalam mendalami pengetahuan hukum dari sudut pandang eksternal dan yang menjadi objek penelitiannya seperti sikap, perilaku, dan kebiasaan sosial dalam masyarakat terhadap hukum. ${ }^{11}$

Pendalaman atas penulisan karya ini dilakukan dengan menunggangi metode penelitian hukum normatif yang bertujuan untuk mengidentifikasi norma-norma dalam pengeksekusian hak tanggungan atau hak pemberian pembebanan atas tanah yang dipailitkan. Riset terkait permasalahan ini memanfaatkan pengkajian sumber-sumber hukum baik dari sumber hukum primer hingga bahan hukum tersier. ${ }^{12}$ Dengan pendekatan penelitian yang dipakai dalam pengkajian karya ini ialah pendekatan perundang-undangan (the statue approach) dan pendekatan analisa konsep hukum (analytical and conceptual approach). ${ }^{13}$ Pencatatan atas bahan hukum yang ditemukan dengan penggunaan metode analisis kepustakaan yang dilaksanakan secara saksama, kritis dan lugas serta pengkajian mendalam terhadap sumber-sumber hukum yang ada relevansi serta kaitannya dengan penelitian yang dikaji. ${ }^{14}$

\footnotetext{
${ }^{10}$ Nugraha, Gede Adi, and GEDE ADI NUGRAHA. HAK EKSEKUSI KREDITOR SEPARATIS TERHADAP OBJEK HAK TANGGUNGAN DALAM HAL DEBITOR PAILIT (STUDY KASUS PUTUSAN NO. 06/PLW/PAILIT/2015/PN. NIAGA. SBY JO. NO. 20/PAILIT/2011/PN. NIAGA. SBY). Diss. Universitas Udayana, 2016.

${ }^{11}$ I Made Pasek Diantha, 2017, Metodologi Penelitian Hukum Normatif Dalam Justifikasi Teori Hukum, Prenada Media Group, Jakarta, h. 11-12.

${ }^{12}$ Soerjono Soekanto dan Sri Mamudji, 2012, Penelitian Hukum Normatif: Suatu Tinjauan Singkat, Cet. Ke-14, Raja Grafindo Persada, Jakarta, h.13.

${ }^{13}$ Johny Ibrahim, 2007, Teori dan Metode Penelitian Hukum Normatif, Bayumedia Publishing, Malang, h. 76.

${ }^{14}$ Bambang Waluyo, 2008, Penelitian Hukum dalam Praktik, Cet. Ke-4, Sinar Grafika, Jakarta, h. 54.
} 


\section{Hasil Dan Pembahasan}

\subsection{Eksekusi Hak Tanggungan}

Target dari Hak Tanggungan (HT) ialah menjamin dan melindungi utangpiutang yang diserahkan oleh pemegang HT terhadap debitor. Andaikata debitor melakukan wanprestasi maka tanah yang diberi beban HT dapat dijual dengan cara dilelang oleh Pemegang HT walaupun tidak diberi izin oleh Pemberi HT dan ia tidak dapat menyatakan penolakan hingga keberatan atas penjualan atas pelelangan tersebut dan jika ada sisa atas penjualan akan dikembalikan ke Pemberi HT (Debitor). ${ }^{15}$ Diketahui bahwa eksekusi HT adalah jika debitor wanprestasi atas janji-janjinya hingga yang dikorbankan obyek HT. Obyek tersebut akan dijual via pelelangan umum menurut eksekusi yang resmi dan pemegang HT berwenang menerima pertama kali dari seluruh atau sebagian dari pendapatan hasil penjualan untuk pelunasan piutangnya. Atas ciri tersebut, HT sebagai hak jaminan atas tanah dikatakan bahwa memberikan kemudahan dan kepastian dalam pengerjaan eksekusinya.

Untuk menjaga keadilan dalam pembagian hasil eksekusi jaminan Hak Tanggungan, secara prinsipnya eksekusi atas objek HT dilelang via pelelangan umum tunduk pada pelaksanaan yang diatur peraturan perundang-undangan dan pemegang HT memperoleh status sebagai Kreditor Separatis. Pemegang HT peringkat pertama mempunyai hak didahulukan atas penjualan objek HT atas kekuasaan sendiri saat mengambil pemberesan piutang dari hasil penjualan tersebut. Disamping itu juga, pemegang HT peringkat pertama mendapatkan hak dalam melakukan penjualan di bawah tangan maupun pelelangan.16

Dalam halnya, debitor atau pemberi HT yang mengalami kepailitan, UUHT juga memberikan kemudahan dan tambahan perlindungan sebagaimana ditentukan dalam Pasal 21 UUHT 17tidak jauh beda dengan ketetapan yang diatur dalam Pasal 14 UUHT yang tetap mengutamakan kedudukan dari si kreditor selaku pemegang SHT. Ketetapan ini lebih mengukuhkan kedudukan dari si pemegang HT yang diutamakan, dengan mengenyampingkan keberlakuan sebab-akibat dari perkara kepailitan si pemberi HT dalam hal ini debitor terhadap obyek HT. Pemegang SHT mempunyai wewenang untuk melelang obyek HT lebih dulu untuk pemberesan piutangnya. Sisanya diinbreng ke dalam boedel pailit pemberi HT.

Pembatasan atas hak eksekusi dalam pengeksekusian HT akibat kepailitan sesuai yang ditetapkan pada Pasal 56 ayat (1) UUK-PKPU yakni terkait penangguhan hak. Secara tidak langgung menyebabkan adanya persepsi bahwa terjadi persamaan kedudukan antara kreditor separatis dengan kreditor lainnya yang tidak mengantongi pegangan hak jaminan kebendaan dan tidak selaras seperti apa yang ditetapkan oleh

\footnotetext{
${ }^{15}$ Sutan Remy Sjahdeini, op.cit, h. 64.

${ }^{16}$ Lihat Pasal 20 ayat (1) UUHT.

17 Lihat Pasal 21 UUHT.
} 
Pasal 55 ayat (1) UUK-PKPU. ${ }^{18}$ Hal tersebut disebabkan karena terpengaruh dari akibat putusan kepailitan itu sendiri terhadap pelaksanaan eksekusi terhadap harta pailit dan bagiannya. Adapun salah satu pelaksanaan hukum yang harus dilaksanakan diakibatkan adanya putusan kepailitan ialah: Perampasan terhadap beberapa barang atau benda dimana sebelum debitor dinyatakan sebagai debitor pailit, ia telah melakukan suatu perbuatan hukum dengan orang lain yang bersumber dari wanprestasi atas perjanjian yang dibuat olehnya. ${ }^{19}$ Hal tersebut menyebabkan harta dari debitor pailit dijatuhi sita jaminan atau sita eksekutorial atas benda-benda yang dijaminkannya. Akibat adanya putusan pengadilan, maka hal tersebut dan upaya hukum atas perbuatan hukum tersebut akan gugur (tidak memiliki kekuatan hukum tetap lagi), karena seluruh harta baik sebelum maupun sesudah kepailitan dimasukkan kedalam kategori utang20 dalam perkara kepailitan. Sehingga benar bahwa dengan adanya dampak dari akibat kepalitan menyebabkan hak dari kreditor separatis dengan kreditor lainnya menimbulkan persepsi adanya persamaan kedudukan antara hak kreditor separatis dengan kreditor lainnya. Dimana seharusnya kedudukan dari para kreditor dibeda-bedakan sesuai dengan yang ditentukan dalam Pasal 1134 KUHPerdata. ${ }^{21}$ Pemenuhan terhadap piutang yang seharusnya diperoleh dan dibayarkan ke kreditor separatis tidak sesuai dengan yang seharusnya diterima. ${ }^{22}$

Ada suatu adagium : "lex specialis derogate legi generalis (hukum yang bersifat khusus mengesampingkan hukum yang bersifat umum)", dimana hak tanggungan telah ditetapkan pada pengaturan secara mengkhusus pada undang-undang hak tanggungan. Atas alas adagium tersebut, ketentuan dalam pasal 56 ayat (1) UUK-PKPU yang mengatur penangguhan hak atas objek Hak Tanggungan tidak terpengaruh dengan adanya putusan pailit sehingga eksekusi langsung tetap dilaksanakan seolah-olah tidak adanya gugatan pailit sebagaimana ditentukan dalam Pasal 14 UUHT dan Pasal 55 UUK-PKPU.

\subsection{Penangguhan hak (stay) Dalam Perkara Kepailitan}

Kepailitan pada prinsipnya merupakan "sita umum atas seluruh harta benda yang dimiliki oleh debitor yang mengakibatkan penguasaan terhadap harta kekayaannya menjadi hilang. Debitor yang di vonis pailit akan diputuskan kekuasaannya atas segala hak keperdataannya untuk mengatur dan mengelola harta kekayaan dan dialihkan penguasaannya kepada kurator dan dimasukkan kedalam boedel pailit dan pengawasannya dilaksanakan oleh hakim pengawas." 23

"Munir fuady menyatakan bahwa kepailitan memiliki tujuan:

1.Menerapkan dengan mutlak asas Pasal 1131 dan 1132 KUHPerdata dalam pembagian pelunasan piutang dibagikan secara proporsional berdasarkan kedudukanya.

\footnotetext{
18 Trianna, Komang, and AA Ngurah Gede Dirksen. "KETENTUAN PENANGGUHAN EKSEKUSI HAK TANGGUNGAN OLEH KREDITUR SEPARATIS AKIBAT ADANYA PUTUSAN PAILIT."h. 3

19 Saputera, Januar Agung. "Kedudukan Kreditur Pemegang Hak Tanggungan Dalam Hal Debitur Pailit." IUS CONSTITUTUM 1.2 (2016). h. 22.

20 Lihat Pasal 1 angka (6) UUK-PKPU.

21 Lihat Pasal 1134 KUHPerdata.

22 Lihat Pasal 59 UUK-PKPU.

23 Lihat Pasal 1 ayat (1) UUK-PKPU.
} 
2.Menghilangkan kewenangan dalam kepengurusan harta kekayaan debitor kepada Kurator agar ia tidak sewenang-wenang dalam memindahtangankan harta kekayaannya dan dapat merugikan kreditor atas perbuatan-perbuatannya tersebut." 24

Para kreditor separatis sebagai pemegang hak jaminan atas kebendaan semacam hak tanggungan, dapat merealisasikan hak eksekusinya bagaikan tidak adanya perkara kepailitan dengan kekuatan hukum title eksekutorialnya. Ketentuan ini ialah pengejawantahan dari prinsip structured prorate. Ratio legis dari ketentuan tersebut untuk menyokong gelar prioritasnya bagi pemegang jaminan dalam penunian seluruh utangpiutangnya. Preferensi tersebut mutatis mutandis yang biasanya ditemukan dalam keberlanjutan kepailitan sesuai dengan aturan pada Pasal 1131 dan Pasal 1132 KUHPerdata.

Pelaksanaan hak preferen dari kreditor separatis yang sedemikian rupa diatur dalam UUHT namun ada pengaturan yang tumpang tindih dalam pelaksanaan hak istimewa kreditor sebagai pemegang jaminan HT, ketika terjadi suatu perkara pailit sesuai dengan yang diatur dalam UUK-PKPU. Dalam pengaturan yang ditentukan oleh undang-undang kepailitan menentukan ketentuan khusus yang mengatur terkait pelaksanaan eksekusinya yakni adanya ketentuan tambahan tentang masa penangguhan hak dan eksekusi atas jaminan HT bagi Kurator dilakukan setelah kreditor pemegang jaminan HT melaksanakan pengeksekusiannya baik dilaksanakan dengan pelelangan umum maupun dibawah tangan yang mana diberi kurun waktu selama 2 bulan dapat memasarkannya sendiri. Pemberian hak stay diatur Pasal 56 ayat (2) UUK-PKPU yang mengatur terkait hak penangguhan oleh kreditor separatis yang dapat mengeksekusi agunan yang dipegangnya dengan masa waktu selama 90 (sembilanpuluh) hari.

Filosofi ketentuan tersebut ialah, dimana pemegang jaminan HT dalam praktiknya sering kali akan menjajakan benda agunannya memakai taksiran jual cepat, dimana harga taksiran itu biasanya dilakukan penjualan dengan harga yang ditentukan dibawah harga pasar. Siasat penjualan tersebut dilakukan tatkala untuk menggenapi kepentingan dari pemegang jaminan HT saja atas tagihannya. Bilamana jika diberlakukan penangguhan sepanjang jangka waktu 90 (sembilanpuluh) hari tersebut menyerahkan peluang kepada kurator untuk mendapatkan harga yang sepatutnya sesuai dengan harga dipasaran bahkan harga yang terbaik maka nilai dari objek HT tidak akan sia-sia hingga dibawah harga pasar. Pada dasarnya hak istimewa atas agunan akan dihitung sebatas nilai piutangnya si debitor, oleh karenanya jika terdapat nilai likuidasi agunan yang dilelang melebihi pelunasan piutang si kreditor kemudian sisa dari hasil likuidasi agunan wajib diserahkan kembali pada debitor. Dalam kepailitan, jika ada kelebihan dari likuidasi atas pelelangan benda jaminan tersebut maka akan dihitung ke dalam boedel pailit. Ketentuan aturan sedemikian tidak akan menimbulkan ketimpangan sepihak namun memfasilitasi terhadap perlindungan hokum bagi kedua bepah pihak baik pemegang HT maupun pemberi HT, sementara kreditor pemegang jaminan HT sama sekali tidak dirugikan. ${ }^{25}$ Walaupun adanya masa ditangguhkan dalam pengeksekusinya, hak atas tanah yang dibebani HT tersebut tidak diperbolehkan untuk dipindahtangankan seperti dijual secara sepihak oleh Kurator.

\footnotetext{
${ }^{24}$ Munir Fuady, 2005, Hukum Pailit Dalam Teori dan Praktek, PT. Citra Aditya Bakti, Bandung. h. 37.

${ }^{25}$ Hadi Shubhan, 2012, Hukum Kepailitan: Prinsip, Norma, dan Praktik di Peradilan, Kencana, Jakarta, h. 172.
} 
Harta pailit yang bisa dipakai untuk boedel pailit oleh Kurator terpatok hanya pada inventorydan/atau current asset berupa benda bergerak ataupun benda tidak bergerak lainnya walaupun nantinya harta pailit tersebut diberi beban dan didaftarkan pada hak jaminan kebendaan lainnya. ${ }^{26}$

\section{Kesimpulan}

Secara umum eksekusi dari jaminan Hak Tanggungan oleh pemegang HT dapat dilakukan secara pelelangan maupun secara dibawah tangan secara langsung tanpa memerlukan putusan pengadilan lagi untuk pengeksekusiannya namun setelah UUKPKPU mengatur adanya pengalokasian bagi seluruh harta debitor dengan jalan sita umum harta baik yang sebelumnya sudah ada hingga harta yang nantinya akan ada termasuk jaminan Hak tanggungan yang diberikan olehnya maka terjadinya penangguhan hak (stay) atas objek jaminan. Ketentuan dalam penangguhan hak tersebut tetap tidak terpengaruh disebabkan UUHT sifatnya lex specialis dbandingkan UUKPKPU sifatnya legi generalis.

\section{Daftar Pustaka / Daftar Referensi}

\section{Buku:}

Bambang Waluyo, 2008, Penelitian Hukum dalam Praktik, Cet. Ke-4, Sinar Grafika, Jakarta

Boedi Harsono, 2007, Hukum Agraria Indonesia: Sejarah Pembentukan Undang-Undang Pokok Agraria, Isi dan Pelaksanaannya, Jilid I, Djambatan, Jakarta

Hadi Shubhan, 2012, Hukum Kepailitan: Prinsip, Norma, dan Praktik di Peradilan, Kencana, Jakarta

I Made Pasek Diantha, 2017, Metodologi Penelitian Hukum Normatif Dalam Justifikasi Teori Hukum, Prenada Media Group, Jakarta, h. 11-12.

Johny Ibrahim, 2007, Teori dan Metode Penelitian Hukum Normatif, Bayumedia Publishing, Malang, h. 76.

Munir Fuady, 2005, Hukum Pailit Dalam Teori dan Praktek, PT. Citra Aditya Bakti, Bandung.

Soerjono Soekanto dan Sri Mamudji, 2012, Penelitian Hukum Normatif: Suatu Tinjauan Singkat, Cet. Ke-14, Raja Grafindo Persada, Jakarta, h.13.

Supriadi, 2018, Hukum Agraria, Sinar Grafika, Jakarta

Sutan Remy Sjahdeini, 2010, Hukum Kepailitan: Memahami Undang-Undang Nomor 37 Tahun 2004 tentang Kepailitani, PT. Pustaka Utama Grafiti, Jakarta

Zaeny Asyhadie, 2005, Hukum Bisnis Proses dan Pelaksanaannya di Indonesia, PT. Raja Grafindo Persada, Jakarta

\footnotetext{
${ }^{26}$ Supriadi, 2018, Hukum Agraria, Sinar Grafika, Jakarta, h.200.
} 


\section{Jurnal:}

Agca, Siti Heiranisya Cita. "Harmonisasi Pasal 21 Undang-undang Hak Tanggungan dengan Pasal 56 dan Pasal 59 Undang-undang Kepailitan dan Penundaan Kewajiban Pembayaran Utang Terkait Kreditor Separatis Pemegang Hak Tanggungan yang Melekat pada Benda Jaminan." Kumpulan Jurnal Mahasiswa Fakultas Hukum 1.8 (2013).

Nugraha, Gede Adi, and GEDE ADI NUGRAHA. HAK EKSEKUSI KREDITOR SEPARATIS TERHADAP OBJEK HAK TANGGUNGAN DALAM HAL DEBITOR PAILIT (STUDY KASUS PUTUSAN NO. 06/PLW/PAILIT/2015/PN. NIAGA. SBY JO. NO. 20/PAILIT/2011/PN. NIAGA. SBY). Diss. Universitas Udayana, 2016.

Paputungan, Nina. "Kajian Hukum Hak Tanggungan Terhadap Hak Atas Tanah Sebagai Syarat Memperoleh Kredit." Lex Privatum 4.2 (2016).

Saputera, Januar Agung. "Kedudukan Kreditur Pemegang Hak Tanggungan Dalam Hal Debitur Pailit." IUS CONSTITUTUM 1.2 (2016).

Trianna, Komang, and AA Ngurah Gede Dirksen. "KETENTUAN PENANGGUHAN EKSEKUSI HAK TANGGUNGAN OLEH KREDITUR SEPARATIS AKIBAT ADANYA PUTUSAN PAILIT."

\section{Online:}

Luqmanul, M Hakim Bastary. (2010). Eksekusi Putusan Perkara Perdata. http://www.ptabandung.go.id/uploads/arsip/149Eksekusi_Perkara_Perdata.p df . Diakses pada 21-01-2019 pukul 10.39 Wita.

\section{Peraturan perundang-undangan:}

Burgerlijk Wetboek (BW), Kitab Undang-Undang Hukum Perdata, Terjemahan Soedharyo Soimin, 1999, Cet. 13, Sinar Grafika, Jakarta.

Indonesia, Undang-Undang Hak Tanggungan Atas Tanah Beserta Benda-Benda Yang Berkaitan Dengan Tanah, Undang-Undang Nomor 4 Tahun 1996 tentang Hak Tanggungan Atas Tanah Beserta Benda-Benda Yang Berkaitan Dengan Tanah, Lembaran Negara Republik Indonesia Tahun 1996 Nomor 3632.

Indonesia, Undang-Undang Kepailitan dan Penundaan Kewajiban Pembayaran Utang, Undang-Undang Nomor 37 Tahun 2004 tentang Kepailitan dan Penundaan Kewajiban Pembayaran Utang, Lembaran Negara Republik Indonesia Tahun 2004 Nomor 131. 